\title{
Protein Nitrogen Unit per Milliliter
}

National Cancer Institute

\section{Source}

National Cancer Institute. Protein Nitrogen Unit per Milliliter. NCI Thesaurus. Code C73578.

A measurement of the strength of an allergenic extract, one protein nitrogen unit/mL $(\mathrm{PNU} / \mathrm{mL}$ ) is 0.01 microgram of phosphotungstic acid-precipitable protein nitrogen dissolved in one $\mathrm{mL}$ of antigen extract. 